\section{ECONOMIC REFLECTIONS OF THE TRANSFORMATION OF SOCIAL DISTANCE CONCEPT IN EVERYDAY LIFE AFTER COVID-19 TO VIRTUAL CONTACT $^{1}$}

\author{
Article Submission Date: 07.06.2021
}

Accepted Date: 22.06.2021

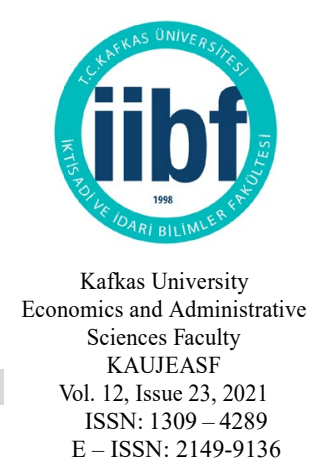

ABSTRACT I Being aware of its own self through social interaction with other people, humanity is discovering new ways to meet the need for socialization and to interact with other people based on communication in the 21 st century. The social isolation that emerged with the Covid-19 pandemic is an important obstacle to the social life of modern people and the sustainability of the entertainment industry. However, in line with the need for socialization, people create their own online social activities by overcoming these obstacles with the communication technologies of the age. This new sector, which emerged at a time of global crisis, allows the formation of new economic capital of digitalization. Within the scope of the study, the adaptation of the entertainment sector, which experienced a shrinkage in its economic volume during the pandemic, to the digital world as a way of salvation is examined. Various online activities carried out in line with this review have been examined in detail, and the future of the sector is discussed with the findings obtained.

Keywords: Digital media, social media, social distance, virtual contact, Covid-19

Jel Codes:: D83, L86, A12

Scope: Management Information Systems

Type: Research

DOI: 10.36543/kauiibfd.2021.024

Cite this paper: Bilici, S. \& Yıldırım, A. (2021). Economic reflections of the transformation of social distance concept in everyday life after Covid-19 to virtual contact. KAÜIIIBFD, 12(23), 554591.

\footnotetext{
${ }^{1}$ Compliance with the ethical rules of the relevant study has been declared..
} 


\section{COVID-19 SONRASI GÜNDELİK HAYATTA OLUSAN SOSYAL MESAFE KAVRAMININ SANAL TEMASA DÖNÜȘÜMÜNÜN EKONOMİK YANSIMALARI}

\footnotetext{
Makale Gönderim Tarihi: 07.06.2021 Yayına Kabul Tarihi: 22.06.2021
}

\author{
Seray BİLİCI \\ Yüksek Lisans Öğrencisi \\ Çanakkale Onsekiz Mart \\ Üniversitesi \\ Lisansüstü Eğitim Enstitüsü, Medya \\ ve Kültürel Çalışmalar Anabilim \\ Dalı \\ Çanakkale, Türkiye, \\ seraybilici.socail@gmail.com
}

ORCID ID: 0000-0002-4938-5939

\section{Arif YILDIRIM}

Dr. Öğr. Üyesi

Çanakkale Onsekiz Mart

Üniversitesi

İletişim Fakültesi, Gazetecilik

Bölümü,

Çanakkale, Türkiye,

arify@comu.edu.tr

ORCID ID: 0000-0002-4446-4865

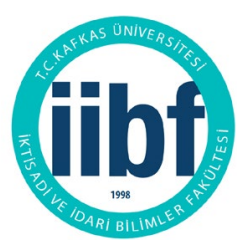

Kafkas Üniversitesi Íktisadi ve İdari Bilimler Fakültesi KAÜIIBBFD

Cilt, 12, Say1 23, 2021

ISSN: $1309-4289$

E - ISSN: 2149-9136

ÖZ I Başka insanlarla kurduğu sosyal etkileşim ile kendi benliğinin farkına varan insanlık, 21. yüzyılda sosyalleşme ihtiyacını gidermenin ve diğer insanlarla iletişim temelli etkileşim kurmanın yeni yollarını keşfetmektedir. Covid-19 pandemisi ile ortaya çıkan sosyal izolasyon, modern insanın sosyal yaşamına ve eğlence endüstrisinin sürdürülebilirliğine önemli bir engel oluşturmaktadır. Ancak, sosyalleşme ihtiyacı doğrultusunda insan, bu engelleri çağın iletişim teknolojileri ile aşarak kendi online sosyal etkinliklerini yaratmaktadır. Küresel bir kriz anında ortaya çıkan bu yeni sektör, dijitalleşmenin yeni ekonomik sermayesinin oluşumuna olanak tanımaktadır. Çalışma kapsamında, pandemi süresince ekonomik hacminde küçülme yaşanan eğlence sektörünün, bir kurtuluş yolu olarak dijital dünyaya adaptasyonu incelenmektedir. $\mathrm{Bu}$ inceleme doğrultusunda gerçekleştirilen çeşitli online etkinlikler detaylı incelenmiş olup, elde edilen bulgular ile sektörün geleceği tartışılmaktadır.

Anahtar Kelimeler: Dijital medya, sosyal medya, sosyal mesafe, sanal temas, Covid-19

JEL Kodu: D83, L86, A12

Alan: Yönetim Bilişim Sistemleri

Türü: Araștırma 


\section{INTRODUCTION}

Mankind began to get rid of the rudimentary structures that we know by carrying out the construction of public sphere alongside social life. In this public sphere, he begins to create daily interactions with other individuals to satisfy desires that he cannot achieve on his own and therefore, the social animal mentioned by Aristotle was born. With this transformation of everyday life with the change in social structure, people have come out of their locked boxes and have built up a new understanding of everyday life through interaction with other people. Although this understanding of everyday life began with the everyday routines of primitive life, it gradually became complex routines over time as one's technology and culture developed. While the routines of everyday life become ordinary, they constitute the foremost important data pool in terms of social studies. As stated by Lefebvre (2014); everyday life is an intermediate and mediating level. In it, the foremost concrete of dialectical movements may be observed as: need and desire, pleasure and absence of enjoyment, satisfaction, and privation (or frustration), fulfilments and empty spaces, work and non-work. The repetitive part, within the mechanical sense of the term, and the creative a part of the everyday become embroiled in a very permanently reactivated circuit during a way which only dialectical analysis can perceive.

Everyday life experiences are always changing within the historical process. These changes occur in proportion to the development of technology and culture. The systematic of everyday life, which exists in the social sense that introduces cultural and technological changes, new cultural practices and new tools associated with their use. Although the constantly renewed technology is used for its own purpose in the first place, but their use is restructured according to the cultural needs of the society. The relationship between technology and everyday life, which began as a trap of primitive times, has resulted in changes in social and spatial phenomena. Once again, Lefebvre (1991) defined that transformation within the social like within the whole of (social) space proceeds from the body, although it so metamorphoses the body that it's going to forget it altogether - while it should separate itself so radically from the body on kill it. Within the body itself, spatially considered, the successive levels constituted by the senses (from the sense of smell to sight, treated as different within a differentiated field) prefigure the layers of social space and their interconnections. The passive body (the senses) and also the active body (labour) converge in space.

Technological developments and transformations in the social field have moved further away from the body and made the social field more massive with technology and has started to exist in nature as a more advanced social creature. 
Much more productive or valuable species, domesticated a much wider range of crops, developed intensified food production and densified human populations more quickly, and entered the modern world as a result with more advanced technology, more complex political organization, and more epidemic diseases. with which one can infect other peoples (Diamond, 1997). This new social order created by sedentary society has to find a solution to the viruses transmitted by the new living things in this new social order in order for human beings to survive among the animal and plant species domesticated by natural selection.

Thus, infectious diseases like smallpox, measles, and influenza arose as specialized germs of humans, derived by mutations of very similar ancestral germs that had infected animals. The humans who domesticated animals were the first to fall victim to the newly evolved germs, but those humans then evolved substantial resistance to the new diseases. When such partly immune people came into contact with others who had had no previous exposure to the germs, epidemics resulted in which up to 99 percent of the previously unexposed population was killed (Diamond, 1997). During the current COVID-19 pandemic dense urban conglomerations function as epicentres for the spread of the coronavirus, as human interactions high in these settings. Hence, to avoid spread of virus, authorities world-wide have prescribed social distancing that ranges from isolation among people in entire metropolitan areas and commanding inhabitants to stay home (shelter in place), to the closing down of meeting places and schools, and voluntary isolation of elders and other vulnerable sub-groups. While these measures can be effective against disease transmission (WilderSmith \& Freedman, 2020).

Since the introduction of computing into society, scholars and technologists have pondered its possible social impact with its rapid evolution, large numbers of applications, wealth of data sources, and global reach to homes, the net has added even more uncertainty. People could use the web to further privatize entertainment (as they have purportedly done with television), to get previously inaccessible information, to extend their technical skills, and to conduct commercial transactions at home--each are somewhat asocial functions that may make it easier for people to be alone and to be independent. Alternatively, people could use the web for more social purposes, to speak and socialize with colleagues, friends, and family through email correspondence and to join social groups through distribution lists, newsgroups, and MUDs (Kraut, et. al. 1998). The intersection of the digital world and real life has been a part of the daily routine for many years and has thus been normalized in human perception. The Covid-19 outbreak in this fastest period of the digital age is a digital pandemic. So much so that the rate of spread of the virus cannot keep up 
with the rate of spread of information and the deception that comes with it. Digital pandemics will be new types of epidemics created by the virus spread by information rather than the actual virus waiting for humanity in the world of the future. Because humanity is making the first trial of digitalization with the Covid19 epidemic. Although digitalization has collapsed at certain points, people have seen that they can completely digitize real life in the world of the future with Covid-19 (Yıldırım, 2020a, p.395). Human beings, who live in a cramped way in city life, have integrated their habits in the real world into digital with the instinct of survival. Business life, education, entertainment venues and even emotional relationships, which are the socialization areas of people, have been moved to the virtual environment. People who cannot meet in the real environment of everyday life maintain their existence through digital applications. This process can also be thought of as the incarnation of virtual bodies in the digital world. This transformative process created by the Covid-19 virus has made people timeless, spaceless, and disembodied.

\section{THE SOCIAL DISTANCE CONCEPT BY COVID-19}

While the aim of every measure taken against the epidemic is to control the health of humanity and to connect it to routine even if there are innovations in everyday life, the social, economic, political and psychological reflections of this new routine will be with digital. In everyday life practices, new versions of the usual phenomena, actions and routines and the integration of these versions into life are observed. The concept of social isolation, which came to the fore after the Covid-19 pandemic, is to isolate the sick person in a separate place so that he or she does not infect other people. The emergence of this concept, which settled in daily life and caused an important transformation, dates back to the 1800 s.

At this point, self-isolation (recorded in 1834) and self-isolation (1841) are now used to describe self-isolation to prevent infection or the spread of infectious diseases. In the 19th century, they were most used to choose countries to isolate themselves from the outside world and economically come from other parts of the world. In addition to these terms used in modern times in the 19th century, recent epidemics, especially the current crisis, have also seen really new words, phrases, combinations, and abbreviations, which are not necessarily for the coronavirus epidemic. And it was created, but it is used more widely since it started. Infodemic (a hybrid word for information and pandemic) is a proliferation of unproven media and online information related to the crisis. The term was coined for the SARS epidemic in 2003 but is also used to describe the current spread of news about the coronavirus (WHO, 2020; Paton, 2020). Within the scope of epidemics affecting public health, events such as the great plague from 
the 14th century, black plague, or black death from the 16th century, which had great effects on public health and turned into a struggle for survival, were experienced. At the end of this struggle, in terms of survival and continuity, concepts such as self-isolation, self-quarantine and quarantine became the main methods for improving public health.

The concept of quarantine is one of the important concepts of public health during the epidemic, and it is one of the oldest and most effective tools for controlling the outbreak of infectious diseases. This public health practice was widely used in Italy in the 14th century, when ships arriving at the Venetian port from the plague-infected port had to moor and wait for 40 days (Italian: quaranta, 40) before the passengers could disembark survivors. 40 days provide enough time to complete the incubation period, however, asymptomatic cases will develop symptoms and can therefore be identified. During the SARS epidemic in 2003, isolation was also successfully implemented as an effective measure (Goh et al., 2006). It is also an important part of the pandemic influenza plan. Quarantine refers to restricting the movement of people who are presumed to have been exposed to an infectious disease but who are not sick, because they are not infected, or are still in the incubation period. Isolation can be applied on an individual or group level and generally involves restrictions on designated homes or facilities. Isolation can be voluntary or mandatory. During the period of isolation, everyone should be monitored for any symptoms. If such symptoms occur, they should be immediately isolated to a designated facility familiar with the treatment of serious respiratory illnesses. Isolation is most successful when cases are detected quickly, contacts can be listed and traced in a short period of time, and quarantine is quickly issued while this announcement is voluntarily made (Maj, 2020).

The terms social isolation and quarantine experienced in everyday life during the Covid-19 process have brought the dynamics of the public sphere to the digital world. This rapid change, experienced with the instinct of survival, is reflected in everyday life as new spaces and new rituals. Fuchs (2020) explains this transformation as follows; People avoid face-to-face social contacts and replace them with mediated social relationships in which communication is organized with the help of telephone, social networks, messaging software and video communication applications (such as WhatsApp, Telegram, Zoom, Skype, Panopto, Blackboard Collaborate, Jitsi, Discord, etc.). Social distancing is not about avoiding communication, but replacing face-to-face communication, which carries the risk of contagion through mediated communication. Social distancing is not about distancing yourself from social and other people, but communication and sociability at a distance. In 2020 billions of people experienced and practiced 
the total collapse and reorganization of their social life. In modern society, daily life can be organized as social practices that occur in different social systems; in these social systems, people continue to spend a certain amount of time with certain people to achieve certain goals. Everybody can use the public space, where we spend free time, meet other people, move from one place to another or organize other aspects of everyday life. For example, work in an office or factory from 9 a.m. at 5 p.m. from Monday to Friday. This means dividing space and time into specific periods of time spent in certain places. Social flexibility, globalization, digitization, personalization, and neo-liberalisation have changed the time and space of everyday life. More and more people are working in different spaces at different times, including their homes and public spaces. Workplaces, homes, and public places have been partially integrated. The boundary between free time and work time, entertainment and work, consumption and production, office, and home, etc. became blurred.

Social distance, which emerged as a result of this uncertainty, was first used on a scale developed by Bogardus in 1925 (Bogardus, 1925). Since its introduction, the Bogardus Social-Distance Scale (1925) has been widely used as a measure of social approval and the "social distance" a respondent perceives between himself and members of different national, racial, religious, or political groups. Eight statements, ranging in gradation from willingness to have a member of one's family marry into the group to preference to exclude a member of the group from this country except as a tourist serve to identify the degree of intimacy acceptable to a respondent towards an average member of a given group. The assumption is that a low social distance score indicates a high degree of acceptable intimacy (Payner, York, \& Fagan, 1974). Bodargus' social distance scale was developed to measure distance in the social sphere, such as people who stay away from each other, not getting married or doing business together. The re-emergence of this concept today is related to the frequent contact environments of people in social life. Close contact in social areas such as crowded business environments, schools and entertainment centres that emerged in connection with urbanization has become a risk factor. In order to prevent the risk of transmission of the disease, states have minimized the contact in everyday life. As can be seen in Figure 1, interpersonal distance is clearly separated in London. This social distance between people has become the routine of daily life over time. 


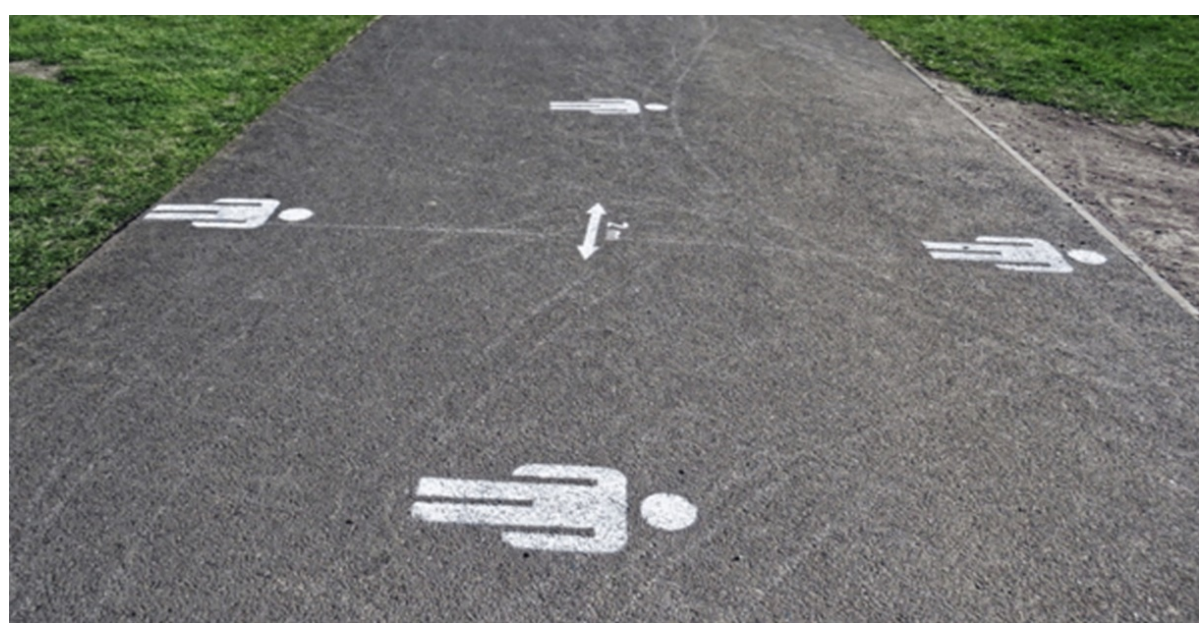

Figure-1: Social distancing footpath markings in London, United Kingdom.

Source: By Acabashi under CC-BY-SA 4.0.

Given the current social adjustments occasioned through the advent of the unconventional coronavirus (COVID-19) across the globe, there has in no way been a higher time to apprehend the effect of digital social interactions on well-being and loneliness. The COVID-19 pandemic has necessitated a reduction in individual contact (social distancing), growing the opportunity that people can also additionally come to be socially isolated. Isolation in addition to the extra stressors and uncertainty related to this crisis pose many socioemotional health risks, especially loneliness (Towner, Ladensack, Callaghan 2021; Tomova et al., 2020). The interruption of social interaction due to social distance has also led to a decrease in the stimuli around people. Considering that the brain is an organ that stays alive as it is used, it is important to have an external stimulus for the brain to stay alive. The decrease in warnings from external factors during the Covid-19 process causes emotional states such as loneliness and anxiety disorder in the individual. The people most affected by this situation are those who live in crowded city life. Because the rapid migration to the city life after industrialization has brought a crowded and congested life form to the present day. Populated areas are dangerous in terms of the rate of spread of the virus. To prevent this spread, states have set rules to maintain interpersonal distance. As can be seen in Figure 1, warning symbols integrated into city life have brought social distance to everyday life. Social distance has physically separated the individual from other people in a crowded society. This distinction prevented the spread of the virus. However, the physical distance experienced also triggered the 
feeling of loneliness in the person.

Google (2021) has started to share the community mobility report in line with the requests that have arisen to support social distance rules. The purpose of this dataset, which also includes Turkey, is to measure social distance through location data. The report includes data from 131 countries. The social areas included in the community mobility report are as follows; It consists of 6 different areas: entertainment centres, markets and pharmacies, parks (public areas), public transportation stations, workplaces and residences. The amount of time spent outside statistically is also reflected in the data provided by Google. The report given in Figure 2 covers the period from April 11 to May 23, 2021.

As stated in this report, the location in the first graphic is retail and recreational areas, and includes places such as restaurants, cafes, shopping centres, theme parks, museums, libraries, and cinemas. According to the Google Community Mobility report, a decreasing movement trend of $71 \%$ is measured in the social areas in retail and recreation chart. When we look at the general situation, the biggest decrease is seen in this area. The locations in the second graphic are markets and pharmacies. This chart includes the following areas: market, food store, market, food shop where specialty products are sold, and places such as pharmacies. According to the Google Community mobility report, a 33\% decreasing movement trend was measured in the social areas in the second graphic. This is a predictable rate as these are areas where basic needs are met. The location in the third chart is parks and includes national parks, public beaches, marinas, dog parks, plazas, public parks. According to the Google Community Mobility report, a decreasing movement trend of $34 \%$ was measured in these social areas. There has been an average decrease in the mobility trend in these areas due to the low risk of virus transmission in open areas. Fourth, public transport stations are examined. It refers to transportation centres such as public transportation centres, metro bus and train stations. According to the Google Community Mobility report, a 50\% decreasing movement trend was measured in the social areas in the fourth chart. One of the reasons why this rate has decreased by half is that it is due to the implementation of social distance rules in public transportation. In the fifth chart, work areas such as workplaces are expressed. This chart measures the movement trend of workplaces. As seen in the chart that there is a decreasing movement trend of $26 \%$ in workplaces. This ratio shows the transformation of office work to work from home. In the sixth chart, the movement trend in social life areas such as residences is measured. There was a $13 \%$ increase trend in residences. As a result of this minimization of interaction in social areas, people spend time at home because they cannot socialize outside. 


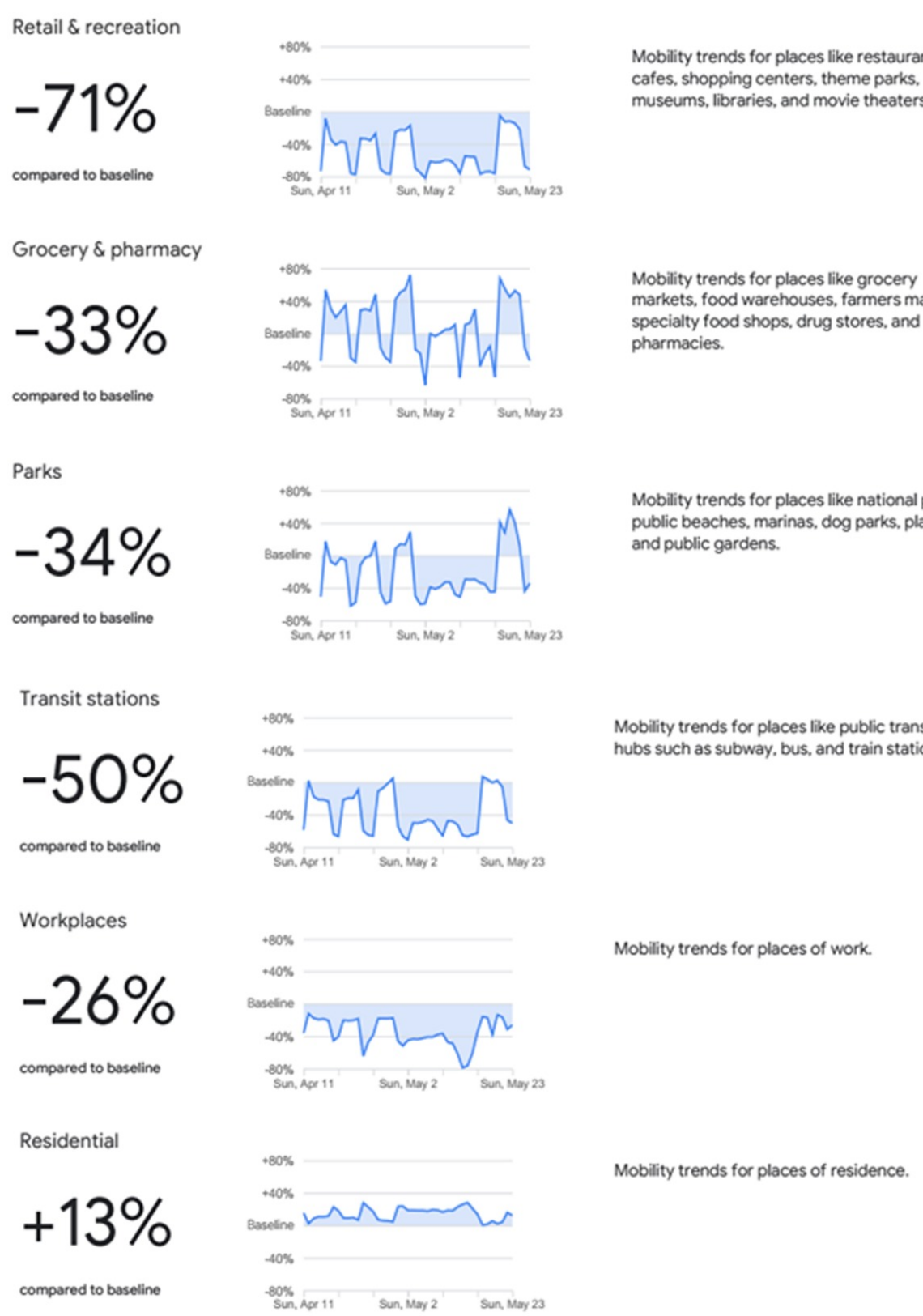

Figure-2: COVID-19 Community Mobility Report of Turkey

Source: (Google, 2021) 
Human interaction in the public sphere continues to decline, as evidenced by the Google Community Mobility Report. Except for areas where basic needs are met, such as markets and pharmacies, human interaction tends to decline. This graphic can be considered as an indicator of the social distance between people. The Covid-19 virus continues on a line whose outcome cannot be foreseen. The set of rules that states apply to everyday life in order to maintain social distance has made people far from the areas where they socialize. Although this situation prevents the spread of the virus, it causes the daily habits to be updated again. In the process of the Covid-19 virus, it is necessary to create a new design in which there is no contact in everyday life, from education to individual relationships and social life.

\section{THE CONCEPT OF VIRTUAL CONTACT AS A RESULT OF}

\section{SOCIAL DISTANCE}

The rapid transformation in daily life, which occurred with the Covid-19 process, can also be considered as a preparatory stage for the transition to virtual communication for human beings. In societies where contact is greatly reduced or even penalized, people need virtual environments and virtual contact to socialize. This situation also causes activities such as concerts, meetings, awards ceremonies, football matches that cannot be organized in real life, to be transferred to the virtual environment. Based on the discourse that human is a social being, it seems that people transfer their new socialization habits to the digital world. One of the human-specific features is the ability to easily adopt newly experienced rituals as a lifestyle over time. The routines and habits formed in this virtual world also provide impressions about how the future will be constructed. Users have the opportunity to participate digitally in spaces where they are not actually present and to perform their social activities in front of the screen. In this context, the concept of social distance that occurs in everyday life has transformed into the concept of virtual contact by creating a fast interaction in the internet environment.

The fear of "losing contact with reality", the fear of living in some "unnatural" artificial world, is not a problem for us and we have chosen to live together for a long time. What is important is the technical ability to create simulations and the political ability to control the context of the presentation. Ethical criticism of Simulacrum accuses us of living in a dream world (Robins, 1996). The Covid-19 virus can also be seen as a process in which the patterns of the usual world are destroyed, leading to a new consciousness. In line with this change, many online formats are integrated into social life. The society is trying to adapt to this rapidly changing new life with traditional habits. This 
transformative process turns the concept of social distance, which emerges in daily life, into the concept of virtual contact. The concept of virtual contact is related to the process of moving social life, education, emotional relationships and business life from social spaces to virtual spaces. In short, virtual contact turns into virtual communication, which was customary in the crowded city life before the epidemic. In line with the possibilities offered by the internet, it enables communities that cannot come together in the real world to meet in the digital world. From this perspective, it can be said that if society is a network, this network is moved from cities to the digital environment, revealing virtual spaces and thus virtual contact.

Social media platforms such as Facebook and Instagram play a key role due to their popularity and physiology-based feedback loops: they can create many weak connections, which can have an impact on the way we experience everyday culture in the actuality. These obligations are governed by the economic and technical regulations of the platform (Appel, G., Grewal, L., Hadi, R. et al., 2020). However, they provide space for discussion and collective negotiation processes. Especially now, in the context of the coronavirus pandemic, social media clearly provides an opportunity for solidarity action. They allow for collective experience and communication about them, whether we are talking with people we know or people we don't know. These types of shared experiences are particularly important in the current crisis because they are the basic condition of solidarity (Stalder, 2014). The resources (time, cost, effort, participation) used for solidarity actions on the Internet vary, but the effectiveness should not be judged in general terms. We understand online activities in social networks as concrete everyday experiences that shape the culture of independence and solidarity in our current society. The examples of the 2020 coronavirus pandemic clearly demonstrate the importance of social media: they have made a considerable contribution to the development of new norms around solidarity. Although \#stayhome was initially a tie, it has increasingly become a norm of solidarity due to its rapid spread on social media. The activities we carry out online will inevitably be reflected in general social interactions, because they are part of our thoughts, opinions, and ultimately part of our identity. Thus, it can be assumed that the numerous digital appeals for social distancing will eventually affect individual behaviour. People will unite and stay home (Fiesse, Haas, 2020). During the pandemic process, many events have started to be organized virtually to prevent contact in the cultural and creative sector. Virtual interactions experienced in online environments prepare the environment for a new understanding of activity.

Covid-19 has also revealed that there may be a different alternative than 
the usual business life. Studies show that virtual conferences are more successful than in-person conferences in terms of the number of participants, and that they are more liked by the participants, and they want to continue to try in the future (Peuler \& McCallister, 2018; Erickson et al., 2020). For this reason, it is important to develop virtual conferences in the dimension of social interaction (Georgi, Xu, Rosca, 2021). Virtual conferences are also academically immensely helpful (Peuler \& McCallister, 2018).

However, more prominent are the suggestions for ritual activities established before COVID-19, which are derived from past physical experience and verbally translated into the online environment. Although the live broadcast experience is different from the physical concert (such as sound, temperature, and lighting) in more aspects, which will undoubtedly affect people's feelings, the audience's persistence in the social dimension stands out. Without physical proximity to other bodies, collective energy seems out of reach, often leading to expressions of frustration. The main question is whether this may be due to less focus on collective emotions in such incidents. In addition, a productive way to explore the importance of the body to collective emotions is online activities that lack physical counterparts, such as game-centric communities on platforms such as Twitch. If these manage to produce a true collective effervescence, then the live broadcast environment may not be suitable for live music (Vandenberg, Berghman, Schaap, 2021). Everyone can find something that suits them, including the 2021 BRIC JazzFest co-hosted with Meshell Ndegeocello and Roy Ayers; the ongoing third season of the Bluebird series for country fans; for those interested in large-scale rock events, U2 the band ended their digital tour "Virtual Road" with a concert in Paris in December 2015, which was broadcast for the first time (Chan, 2021).

During this pandemic, the performing arts in open space need to be diverted. Performances that actually involve the interaction between artist and audience as the most ideal interaction in the abundance and intensity of the performing arts should now be able to break bonds through social distancing and physical distancing. Art and work are separate. Art is a kind of leisure activity, which refers to activities that make a living outside of working hours. Art is a relaxing activity that can relieve the tension caused by working hard to earn a living (Kusuma, 2020). Digital media and social networks were chosen as the right step as performance spaces that trigger changes and transformations in the performing arts. The virtual concerts during the epidemic became very lively, allowing artists to work passionately. Lokki et al. (1999) pointed out that creating a virtual concert experience, in which vision (visual participation) and hearing (auditory participation) are artificially generated, is a challenging task. The 
virtual concert experience can be made even in real time, with the interaction of the listener and the virtual environment. Therefore, when organizing a virtual concert, of course not only the artist's artistic experience, but also the artist's ability to learn technology and digital.

Virtual events, along with the process that started with Covid-19, are also preparing the environment for larger organizations. So much so that the SuperBowl Pegame Show event, with the famous pop musician Miley Cyrus as the headliner, and the performance of famous names such as Rebel Wilson, Kane Brown, Ajani Huff, Dave Jorgendson, Adam Devine and Baltimore Ravens, was broadcast online via TikTok Tailgate to 7500 healthcare professionals who were invited. This broadcast is a special case in that it was held before Super Bowl LV, the official broadcast channel of the event, and was for one group only (Pham, 2021). On the other hand, the concert event "Bang Bang Con: the Live" presented by Korean pop group BTS through Kiswe Mobile which is a cloud-based remote production studio software, broke the attendance record. After this event, it broke a new record by bringing together 993.00 audiences from 191 countries with the 2-day virtual concert event "Map of the Soul ON:E". Despite the ticket prices varying between $\$ 45-55$ for a single day and $\$ 81-91$ for 2-days for the basic "Hdmulti-view" package in the USA, the $4 \mathrm{~K}$ broadcast package offered in the future was also consumed in a short time. The event, which was originally planned as a real concert, was re-edited and virtualized in a way that would force technological possibilities due to the pandemic. The audience was able to switch between 6 different cameras in the concert, which took place on 4 different stages with performances of 23 songs that lasted in 150 minutes (Dahir, 2020). According to Big Hit metrics, the show reached a peak of 756,000 concurrent viewers in 107 countries and territories. Attendance was the equivalent of 15 shows at a 50,000seat stadium and was the biggest audience for a paid virtual concert. Big Hit added that the concert also helped grow BTS' fan club, known as the ARMY, by 10,000 members (Frater, 2020).

In addition, registration in the Digital Concert Hall is free and gives you access to numerous interviews, films from the educational program and a playlist with the main conductor Kirill Petrenko, with which you can try out the Digital Concert Hall without obligation. Tickets or subscriptions give you access to all live streams and videos anytime on the device of your choice. Each season, about 40 concerts are broadcast live, which will also be available in the concert archives in the future. The archive already contains hundreds of recordings with all the great classical music artists (Digital Concert Hall, 2021). Yet another one, Social Distancing Festival, by its own definition, is an online artist network where artists who have been economically affected by quarantines during the pandemic can 
showcase their work. This project, which aims to cover not only music but all other performative and formal arts, allows the interaction of artists, art and audience to take place online and the sustainability of art during the pandemic process. Within the scope of the project, Alberta, British Columbia, California, Colorado, Florida, Georgia, Manitoba, Massachusetts, Minnesota, New Brunswick, New Mexico, New York, Northwest Territories, Nova Scotia, Nunavut, Ohio, Ontario, Prince Edward Island, Quebec, Saskatchewan, 400 applications from the USA and Canada were reviewed, including Washington, Washington DC and the Yukon, and 26 artists were selected and funded (The Social Distancing Festival, 2021).

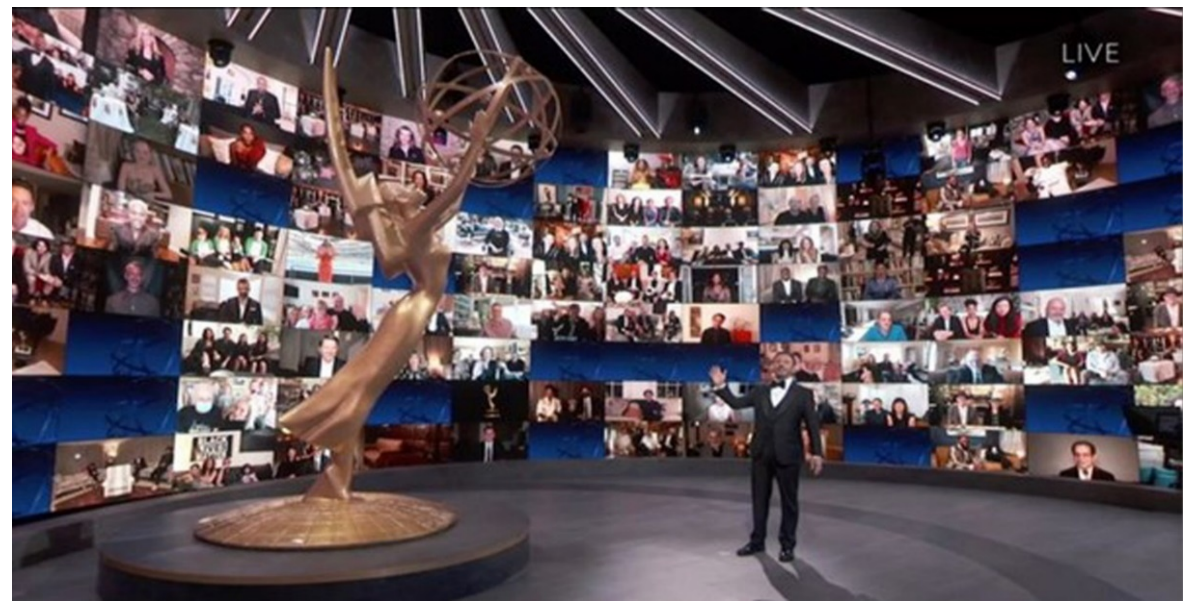

Figure-3: 2020 Emmy Awards Virtual Organized

Source: (Blickley, 2020)

Although these new solutions in the field of art belong to the online world, similar transformations are seen in the TV industry. The live broadcast connections and participants, which have already existed in the news bulletins since the early days of TV, are not limited to news bulletins this time, but also find themselves in major organizations around the world. So much so that the 2020 Emmy Awards literally took the form of broadcasting a virtual ceremony on TV. The cast in the 130+ TV series broadcast on screens throughout 2020 were connected to the venue where the ceremony was held online, and the awards were distributed in this way (Blickley, 2020). For the first time in Emmy history, celebrities attended the ceremony not from the seats in the hall where the ceremony was held, but from the seats in the hall of their own homes. This situation has caused even well-established projects to have to adapt radically to the digital age. 


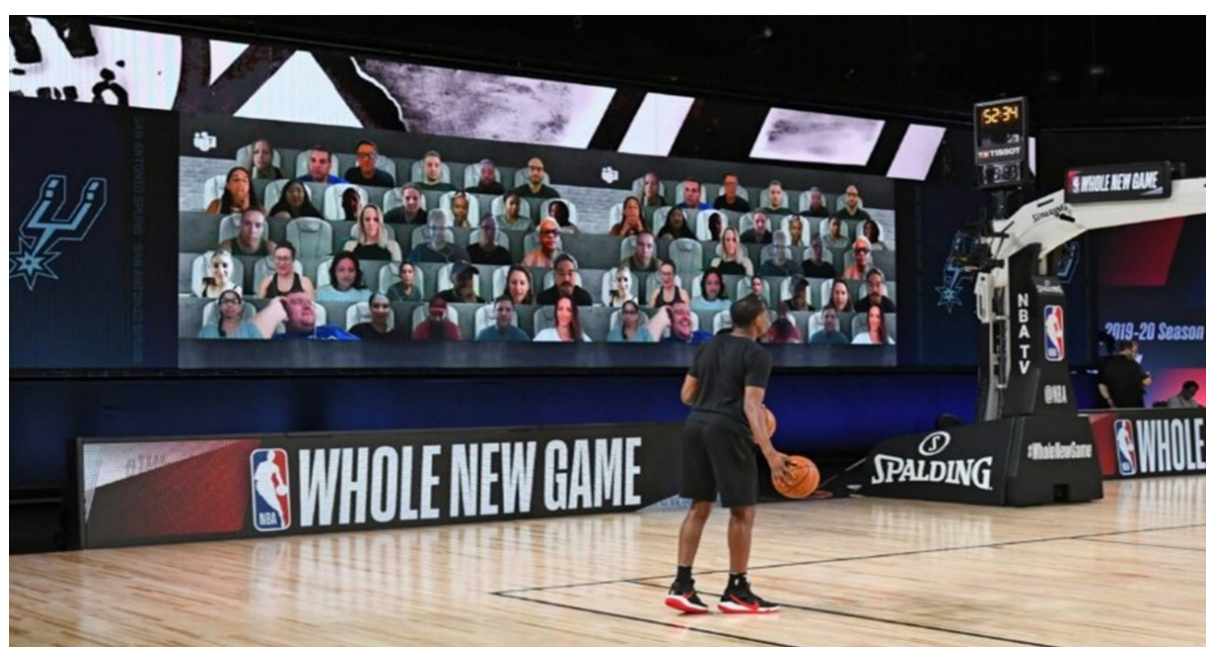

Figure-4: Virtual cheering of fans at NBA game

Source: (Powell, 2020)

Due to the pandemic, the necessity of being online has not only been limited to award ceremonies but has also found a place in the sports world. Playing sports competitions without audiecens both negatively affects the performance of the athletes and damages the sense of unity of the fans who support the team. So much so that in some football competitions, the mock-up audineces placed on the audience seats and the cheer recordings of the fans are broadcast throughout the competition, trying to increase the motivation of the athletes. This year, since audience participation could not take place in league matches by social distance rules, audiences attended the games at the Disney Campus of the NBA online from their homes through the screens lined up around the pitch. "We're just looking forward to having more fans, more names and expanding on this. Being able to have cheers and fans reacting is so much a part of our sport"said Sara Zuckert, the NBA's head of next-generation broadcasts. explained why this is necessary (Powell, 2020).

Virtual events that take place during the pandemic period offer new advantages for the audience. That is to say, it has become possible for large audiences to watch a single event at the same time, which cannot be found in the same environment under normal conditions. As an example of this situation, Dynamo Dresden said they sold more than 72,000 "ghost" tickets for the cup match at home to Darmstadt on Tuesday, even though it was played in an empty stadium. With fans barred from attending because of the Covid-19 pandemic, the third-tier side decided to put tickets on sale at $€ 5$ each and appealed to fans to buy 
them out of solidarity. Even the former East German champions were surprised when 72,112 "ghosts" bought tickets, nearly three times their average attendance last season and more than twice their stadium's capacity. Dresden said on their website that it would have been the third-biggest crowd ever to watch one of their games. The Rudolf Harbig Stadion only has a capacity of 32,000 (Guardian, 2020). The concept of social distance, which has settled into everyday life in order to prevent the spread of the epidemic, has led to a decrease in the contact area of people. This situation has moved socialization spaces to the digital environment. After this unexpected crisis, a transition to a world order in which physical reality and virtual reality are intertwined has begun.

\section{ECONOMIC REFLECTIONS OF VIRTUAL CONTACT IN}

\section{THE FRAMEWORK OF THE DIGITAL PANDEMIC}

Social interaction is both the biggest obstacle and the greatest success of digital socialization. Social media, like culture, is inclusive at the social level, and it requires a large number of repetitions of a phenomenon and a large number of repeaters for social interaction. The digital world has greater access opportunities than the real world for the repetition of a phenomenon and the number of people who repeat it (Y1ldırım, 2020b, p.53). The nature of virtual space may be different from the so-called real space. In this case, the real space refers to the space we know on the earth. Since many phenomena in real space, such as continuity or perspective, are possible in virtual space, the two overlaps. Although the real space is limited to reality, the virtual space [exists due to power or possibility] is created by human thoughts, so it is only limited by thoughts (for real-time immersive presentations, it is currently the speed of computers) This freedom gives virtual space unlimited qualities like free (Kieferle, 2000). New media environments that emerged as a result of the rapid development of communication technologies reveal new audience and broadcaster practices. Changes experienced on the viewer side also occur on the side of content producers. The fact that the content created by the user is consumed by the user is important in terms of targeting the content more accurately (Y1ldirım, 2020b, p.65). Although the Covid-19 pandemic emerged as a health crisis, its results caused many economic changes.

The economic impact of the social distancing rules implemented to contain the spread of the Covid-19 virus depends on the structure of the production network. In fact, the modern economy is characterized by the multiple interdependencies that companies form in their production processes (Barrot, Grassi and Sauvagnat, 2020). The cultural and creative sector, vital to the wellbeing of the European economy and its citizens, has been seriously harmed by the measures taken to combat the spread of the Covid-19 pandemic. Suddenly, 
with the virus outbreak, global production ceased, and the entire value chain was affected: events were postponed or cancelled, and presentations related to marketing, distribution and tours were also postponed or cancelled. Bookstores, cinemas, concert halls, clubs, museums, theatres, heritage sites or art galleries have been closed. As from June 2020, cultural and creative sector re-started production (in audio-visual), places dispensing cultural goods and services were back in business with life venues (to the exception of clubs) partially reopening based on stringent sanitary obligations aimed at enforcing social distancing rules. The sector lobbied without success to be exempted from curfew or lockdown measures on the evidence of the ability to implement efficient social distancing rules. However, like bars, restaurants and nightclubs, the cultural and creative sectors have become the main victims of the new hygiene measures aimed at restricting mobility and social contact (KEA European Affairs, 2020). According to the European Festival Association (EFA) (2020), the average loss is estimated at 150,000 euros and the median for each festival is 40,000 euros, which has a great impact on the tourism sector and the local economy. Total sales of artworks worldwide fell $97 \%$ at Christie's, Sotheby's, and Phillips during May, from nearly USD 2.9 billion in 2019 to USD 93 million in May 2020. Overall, Art Basel (2020) reports that compared with 2019, gallery sales in the first six months of 2020 have fallen by an average of $36 \%$ (an average of $43 \%$ ), and the downward trend is expected to continue.

\section{YES, LIVE IS OUTPACING THE GROWTH OF OTHER TYPES OF ONLINE VIDEO}

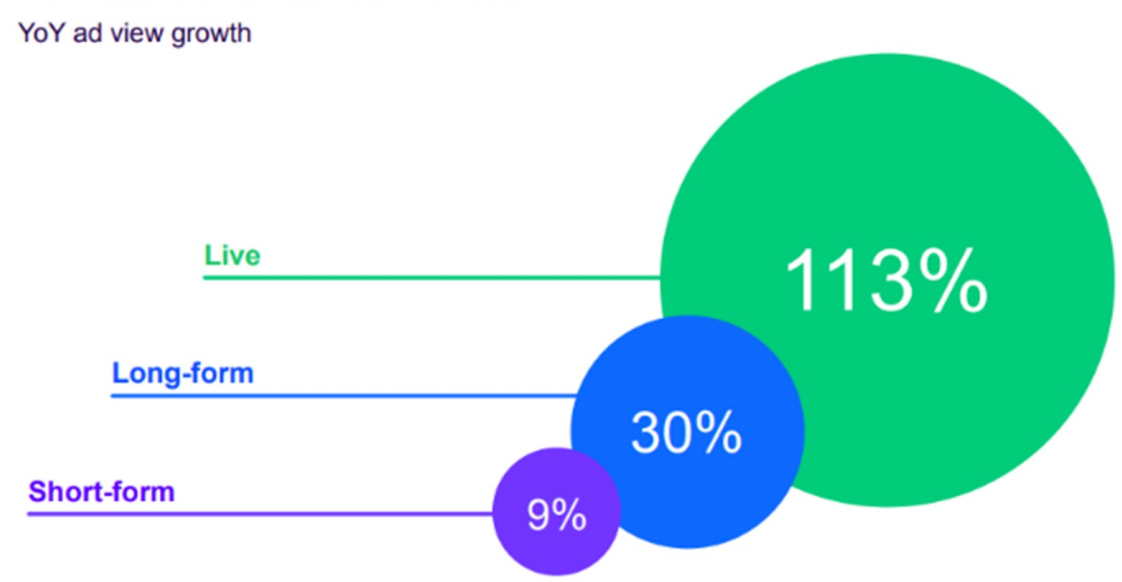

Figure-5: Video Formats Preferred in Social Media

Source: (Market Research Future, 2020) 
After Covid-19, it is seen that people are now entering the virtual ecosystem. As seen in Figure 5, the rates of video viewing options on social media platforms in 2020 are given. In line with these rates, people watch live broadcasts at a rate of $113 \%$. Afterwards, 30\% long form and $9 \%$ short from videos are watched, respectively. The live streaming demand rate is the largest in the chart and there is a big difference with other video streaming options. This shows that people who must stay at home due to the pandemic attach importance to instant interaction. It is obvious that the reason for this situation is due to the decrease in the contact rate. People act with the motive of interacting instantly and lively from the virtual environment with other individuals whom they cannot meet in real life.

An example of this situation is the increase in Instagram live broadcasts between March 8 and March 15. IG Live, which hosts Instagram livestreams that users can access through Instagram Stories, was previously overlooked by brands, but it has exploded practically overnight. According to Jeannette Ornelas, senior digital marketing analyst at Mintel Intelligence Group Comperemedia, between March 8 and 15, mentions of IG Live on Instagram and Twitter soared by 526\%. This feature is attractive to companies because they are struggling to rank social content that is logically feasible and relevant to the audience during the quarantine period. With the adoption of beauty brands and rising ratings, live broadcasts will have staying power beyond the coronavirus. Estee Lauder Companies', Bobbi Brown, for example, listed a schedule of daily social distancing-related livestreams with makeup artists. This included tutorials on video conferencing makeup and makeup spring cleaning IG Live, which hosts Instagram livestreams that users can access through Instagram Stories, was previously overlooked by brands, but it has exploded practically overnight (Flora, 2020). In the initial stages of the European societal lockdowns, musicians rapidly moved to the virtual sphere, with livestreams in particular proving to be a vital resort for artists and audiences. Although the practice of livestreaming was around long before the pandemic. But when venues closed, there was little choice but to shift focus to the free and accessible livestreaming services of Facebook, Instagram and YouTube (Vandenberg, Berghman, Schaap, 2021). In this process, some of the live broadcasts on social media are virtual concerts. 


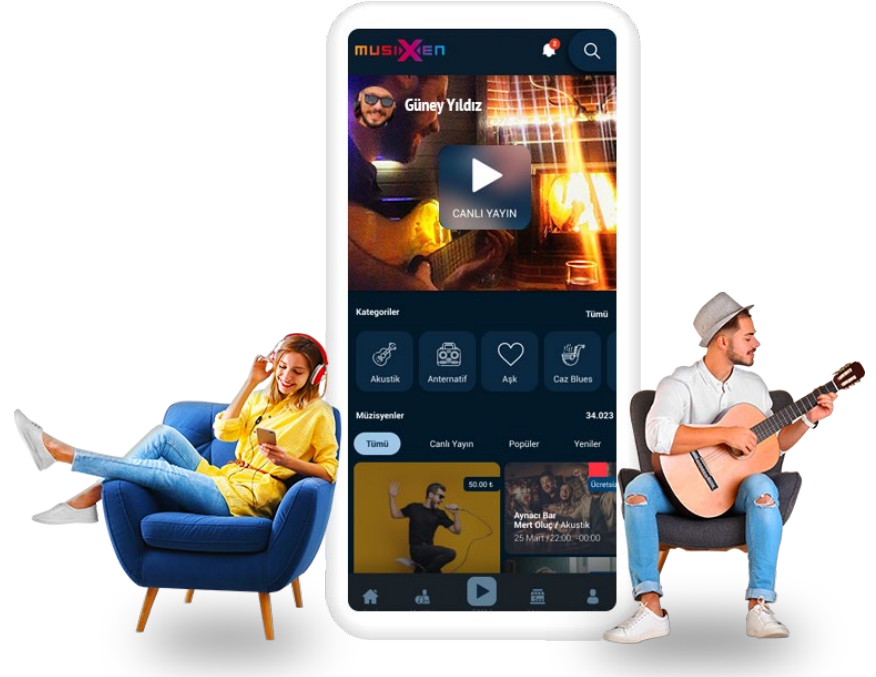

Figure-6: Virtual Concert and Monetization App Musixen

Source: (Musixen, 2021)

An example of this is the Musixen (2021) application, which allows musicians to give concerts online. In short, the Musixen application is a platform that enables musicians to perform digitally with various gamification methods (such as breaking plates, clapping, pouring roses). The Musixen application serves not only in Turkey but also globally. While this application organizes 2,000 live concerts per month, it has a total of 300,000 users. One of the features of the platform is to turn online concerts into a commercial service. The platform has its own currency called "diamond". Users can buy the ticket of the musician they like with "diamond" or the venues where they will listen to music in the application can be purchased with "diamond". This feature, which provides space change, aims to clone real life in a way. In addition, since the application serves interactively, users offer options to request songs, communicate with musicians and messaging between users. In this context, the Musixen application is an application designed to provide an experience close to the real-life concert event.

Virtual concerts have gradually led to the formation of a different economy during the pandemic. In this context, SuperM came to a screen near you and other fans in over 200 countries in April 26th at 3 p.m. for their virtual live stream concert. Their live stream marked the first show in SM Entertainment's ground-breaking broadcast concert series Beyond LIVE, which featured a wide array of camera shots, 3D backdrop graphics, augmented reality that's never been 
experimented on online concerts, and digital communication tools between the K-pop boy band and online concertgoers to fully immerse them in the live experience. Global viewers can also choose to watch with subtitles in several different languages. Tickets were available to purchase for $1,500 \mathrm{~V}$ coins on $\mathrm{V}$ Live, a South Korean live video streaming app that allows users to buy media content with virtual currency. According to a help page, $\$ 1$ buys $50 \mathrm{~V}$ coins, meaning the standard ticket price for the event rounds out to $\$ 30$. Users become not only viewers but also consumers on social media platforms. These consumption habits and ways of spending money are changing. As in the example of the SuperM concert, the fans of the group can buy tickets for a virtual currency called V coin, apart from the dollar rate, to buy tickets (Mamo, 2020). As seen in Figure 6, there are virtual concert tickets of SuperM group. These packages, which are specially designed for fans, include the concert recording those fans can watch at any time, the band's special videos, the concert light and the plane ticket that makes you feel as if you are going to a concert. These packages are sold separately from the ticket prices. This situation shows that during the Covid19 process, the users feel like they are there virtually in places where they cannot take place in real terms. Concert lights were also offered for sale, as if they were in a concert environment, for this concert where fans attended from their homes. According to this example, the prohibitions created by social distance do not prevent consumption.

EVENT 1

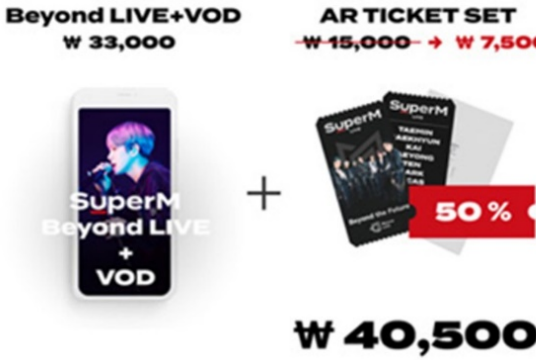

EVENT 2

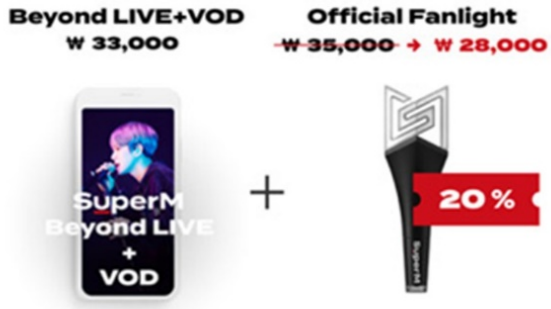

W 61,000

Figure-7: Virtual Concert Tickets

Source: (Global Yes24, 2021)

With the transformation caused by the Covid-19 process, it is not known in which direction the entertainment activities economy will evolve. As an example, is given in the title of Virtual Contact, the world-famous Korean group BTS's virtual concert event named "Bang Bang Con: the Live" set the attendance 
record. As a different example, the tickets for the Map of the Soul On:e shows were being sold for about $\$ 45$ for a one-day pass and around $\$ 90$ for the two-day pass, and according to Big Hit, BTS's record label, 993,000 viewers tuned in from across 191 countries (Willman, 2020). Considering under normal conditions, it would be impossible for 993,000 people to watch an event at the same time, while virtual events turn this disadvantage into an advantage, at the same time increasing the economic return of the events at a much higher rate than expected. When Table 1 regarding the concert activities is examined, Eddie Vedder and Phoebe Bridgers performed together for \$25 in 2021, while the concert ticket that Eddie Vedder sold at the Innings Festival before Covid-19 was \$99. Phoebe Bridgers performed for $\$ 72$ in 2019. While the virtual concert ticket price of Russian DJ Flux Pavilion is $\$ 10$, it is $\$ 49$ before the pandemic. While the worldfamous pop star Justin Bieber took the stage for \$22.50 during the Covid-19 process, tickets were sold for $€ 279$ during his European tour in 2017. Although there are 3 years in between the concerts and there is a big difference between the virtual concert fee of Justin Bieber and the real concert fee. While Gorillaz group sold virtual concerts at $\$ 15$, real concert tickets were sold at $\$ 143$. World-famous female pop star Dua Lipa held her virtual concert for free. The ticket price before the pandemic was \$251. Likewise, Major Lazer organized the 2021 virtual concert for free and the real concert price is $\$ 77$. While performing for $\$ 14.99$, the famous metal music group Metallica sold tickets for $\$ 103.3$ before the pandemic. Billie Eilish sold tickets online for \$30. Billie Eilish's real concert price is $\$ 101.75$. During the pandemic, Katy Perry and David Guetta held their virtual concert together, and the ticket price of this concert is $\$ 30$. The ticket price of Katy Perry's latest world tour is $\$ 325$. David Guetta performed on the European tour for $€ 89$. Korean music group Monsta $X$ has set virtual concert sales at \$20. The band's 2019 ticket price was $\$ 98.55$. Again, Korean pop group BTS set the first day of the sale of their two-day virtual concert between \$45-55. The cost of the concert for two days was sold between $\$ 81-91$. The group's ticket prices for 2019 are $\$ 232$. This table shows that the virtual concert prices organized during the Covid-19 process are sold at much lower prices than the real concert prices. For example, the ticket sales price of a concert organized by Justin Bieber in 2017 does not even correspond to half the price of the virtual concert ticket price in 2021. This situation shows that if the Covid-19 process continues for a long time, the dynamics of the entertainment sector economy may need to be rearranged. 
KAÜiiBFD 12(23), 2021: 554-591

Table-1: Virtual Concert Dates and Ticket Prices

\begin{tabular}{|c|c|c|c|}
\hline $\begin{array}{l}\text { DATE } \\
(2021)\end{array}$ & ARTIST & TICKET PRICES & $\begin{array}{l}\text { TICKETPRICES (BEFORE } \\
\text { 2020) }\end{array}$ \\
\hline 14 February & $\begin{array}{l}\text { Eddie Vedder } \\
\text { Phoebe Bridgers }\end{array}$ & $\$ 25$ & $\begin{array}{c}\$ 99(\mathrm{E} . \mathrm{V} .) \\
\text { (İnnings Festival one day will } \\
\text { cost prices) } \\
\$ 72(\text { P.B.) }(2019) \\
\end{array}$ \\
\hline 14 February & Flux Pavilion & $\$ 10$ & $\$ 49(2018)$ \\
\hline 25-26 July & $\begin{array}{c}\text { Katy Perry } \\
\text { David Guetta }\end{array}$ & $\$ 30$ & $\begin{array}{l}\text { \$325 (K.P.) (2017) } \\
\text { \$89 (D.G.) (2019) }\end{array}$ \\
\hline 8 August & Monsta X & $\$ 20$ & $\$ 98,55(2019)$ \\
\hline 24 October & Billie Eilish & $\$ 30$ & $€ 101,75(2019)$ \\
\hline $\begin{array}{c}10-11 \\
\text { November }\end{array}$ & BTS & $\begin{array}{c}\$ 45-55 \text { (single day) } \\
\$ 81-91 \text { (two day) }\end{array}$ & $\$ 232(2019)$ \\
\hline 14 November & Metallica & $\$ 14,99$ & $\$ 103.33(2018)$ \\
\hline 18 November & Major Lazer & FREE & $\$ 77(2019)$ \\
\hline 27 November & Dua Lipa & FREE & $\$ 251(2017)$ \\
\hline 5 December & Gorillaz & $15 \$$ & $\$ 143(2018)$ \\
\hline 31 December & Justin Bieber & $\$ 22.50$ & $€ 279(2017)$ \\
\hline
\end{tabular}

In addition to concert events, art events such as theater and opera were moved to digital platforms. Concerts of the Berlin Philharmonic Orchestra are broadcast online from the Digital Concert Hall site. This application offers options as live or recording. Hundreds of recording options can also be watched on this platform, which offers the option to broadcast approximately 40 concerts live every season (Digital Concert Hall, 2021). According to the membership system in Table 2, a monthly membership fee that requires automatic renewal is $€ 14.90$, a twelve-month membership fee is $€ 149.00$, a monthly membership that does not require automatic renewal is $€ 19.90$ and a weekly membership is $€ 9.90$. The online platform where Broadway musicals are broadcast is the Broadwayhd site. This application offers the option to watch without waiting for the curtain time interval. Many shows are presented inside the platform, from the classic broadway musical, films, theaters, nunsense collection, bingeable series and performance art (Broadway, 2021). The National Theater Home platform, on the other hand, is an online platform where British theater plays are added every month in 2020 . The platform costs $£ 99.99$ a month and $£ 9.99$ a year. The Royal Shakespeare Company offers the option to watch Shakespeare's plays by new and contemporary authors for $€ 50$ per year (Company, 2021). The Digital Theater platform, located in the last part of Table 2, offers individual users the option to watch over 400 world's most famous theater plays, musicals, operas, dances and classical music concerts. In addition, for educational institutions, it adds behind- 
the-scenes footage, interviews, written analysis and more than 450 production viewing options. Also, more than 1200 curriculum-related data sources are shared for educational institutions. This app costs $€ 9.99$ per month, while the rental is $€ 7.99$.

Table-2: Prices of Online Theatre and Opera Viewing Platforms

\begin{tabular}{|c|c|c|c|}
\hline \multirow[t]{2}{*}{ NAME } & \multirow[t]{2}{*}{ WEBSITE } & \multicolumn{2}{|c|}{ SUBSCRIPTION } \\
\hline & & MONTHLY & YEARLY \\
\hline $\begin{array}{l}\text { Berliner Philharmoniker Digital } \\
\text { Concert Hall }\end{array}$ & digitalconcerthall.com & $€ 14.90$ & $€ 149.90$ \\
\hline BroadwayHD & broadwayhd.com & $\$ 8.99$ & $\$ 99.99$ \\
\hline National Theatre Home & nationaltheatre.org.uk & $£ 9.99$ & $£ 99.99$ \\
\hline Grange Park Opera & grangeparkopera.co.uk & $€ 20.0$ & - \\
\hline Royal Opera House & roh.org.uk & Donate & Donate \\
\hline Royal Shakespeare Company & rsc.org.uk & $€ 50.0$ & - \\
\hline Digitaltheatre & digitaltheatre.com & $€ 9.99$ & - \\
\hline
\end{tabular}

During the Covid-19 process, arts and entertainment events are held online at lower prices than before the pandemic. In addition to these activities, private life relations were also transferred to the digital environment. Today, when face-to-face communication is risky, users meet with the opposite sex through social media applications. This is not only dating, but also online dating. At home, alone and in some cases without a job, single people are spending more time swiping right on dating apps to find love, particularly in the cities hardest hit by the virus: Bumble reports a 21\% increase in messages sent in Seattle, 23\% increase in New York City and 26\% increase in San Francisco since March 12, a day after the World Health Organization labelled the coronavirus a global pandemic. The use of in-app video chatting on Bumble, a feature many users didn't even know existed before the coronavirus spread, increased $93 \%$ across USA between March 13 - the day President Donald Trump declared a national emergency - and March 27, with in-app calls and video chats averaging 29 minutes. Hinge, similarly, saw a 30\% increase in messaging on the app in March, compared to February, and has responded by launching an in-app "date from home" feature that, if both users agree, launches a video chat or phone call (Dockterman, 2020).

Membership fee information of online dating and dating platforms is given in Table 3. According to the Tinder application, photos must be uploaded to the system first. If the user who likes the photo swipes to the right, it means liking the user, if he/she swipes to the left (nope), it means disliking the user. According to this information, the application provides connection by matching 
users. While it provides unlimited likes and five super likes to Plus members, plus membership also includes ads. While the Gold membership provides information about which users the users like, the Platinum membership provides the messaging before the match and the record of the people liked in the last seven days (Beck, 2021). Bumble, on the other hand, acts with the slogan "we want to help you stay connected virtually, even when physically separate" (Bumble, 2021a) during the pandemic process. The application offers users the option of matching and messaging. Allows location switching to allow people in different regions to contact you based on Premium membership. This situation can be given as an example of the aforementioned loss of space and the emergence of dislocation. The Coffee Meets Bagel (2021) app also offers the option of matching and messaging with the phrase "we found a way to stay tight despite the distance". Coffee Meets Bagel's Premium membership also offers the option to communicate with unmatched people. The Plenty of Fish app is claimed to have more than 3 million members. The application provides the ability to make calls and send messages without having to match. With the premium membership, it aims to expand the profile and make it more visible (Beck, 2021). Being more visible with this feature can be considered as another way of showing presence in the digital world. The premium features of the Eharmony application also offer unlimited match and search options. Okcupid's application asks the users questions and matches them according to the answers. Okcupid provides more than 91 million connections each year and promises 50,000 meetups each week. While Okcupid Basic prevents the display of ads in the membership, in the premium membership, it offers the option to see the answers of other people to the questions (Okcupid, 2021). The question feature of the Okcupid app shows that human beings need an algorithm to determine dating and mutual compatibility. 
Table-3: Prices for Online Dates Platforms ONLINE DATING PLATFORMS PACKAGE PRICEES/YEAR

\begin{tabular}{|c|c|c|}
\hline \multirow{2}{*}{ Tinder } & Plus: & $£ 4.99-£ 19.94$ \\
\cline { 2 - 3 } & Gold: & $£ 13.99-£ 29.49$ \\
\cline { 2 - 3 } & Platinium: & $£ 18.14-£ 36.49$ \\
\hline Bumble & Premium: & $€ 32.99$ \\
\hline Coffee Meets Bagel & Premium: & $€ 34$ \\
\hline Plenty of Fish & Premium: & $€ 13.33$ \\
\hline Eharmony & Premium: & $€ 16.66$ \\
\hline \multirow{2}{*}{ Okcupid } & Basic: & $€ 19.49$ \\
\cline { 2 - 3 } & Premium: & $€ 43.99$ \\
\hline
\end{tabular}

In online dating applications, an increase in usage rates is observed in 2020. An example of this rapid increase is given in Figure 7. Bumble (2021b) CEO Whitney Wolfe Herd has directly encouraged users to date virtually and avoid meeting in person, writing in a public blog post that "we want to help you stay connected, even when physically apart." She hopes people will use Bumble's in-app video chat feature (launched without much fanfare last year), another tool for its female-centric audience to gauge a potential date. With more people at home, Bumble saw use of this function spike $93 \%$ between March 13 and March 27. The average call was nearly 30 minutes long (Brown, 2021). 


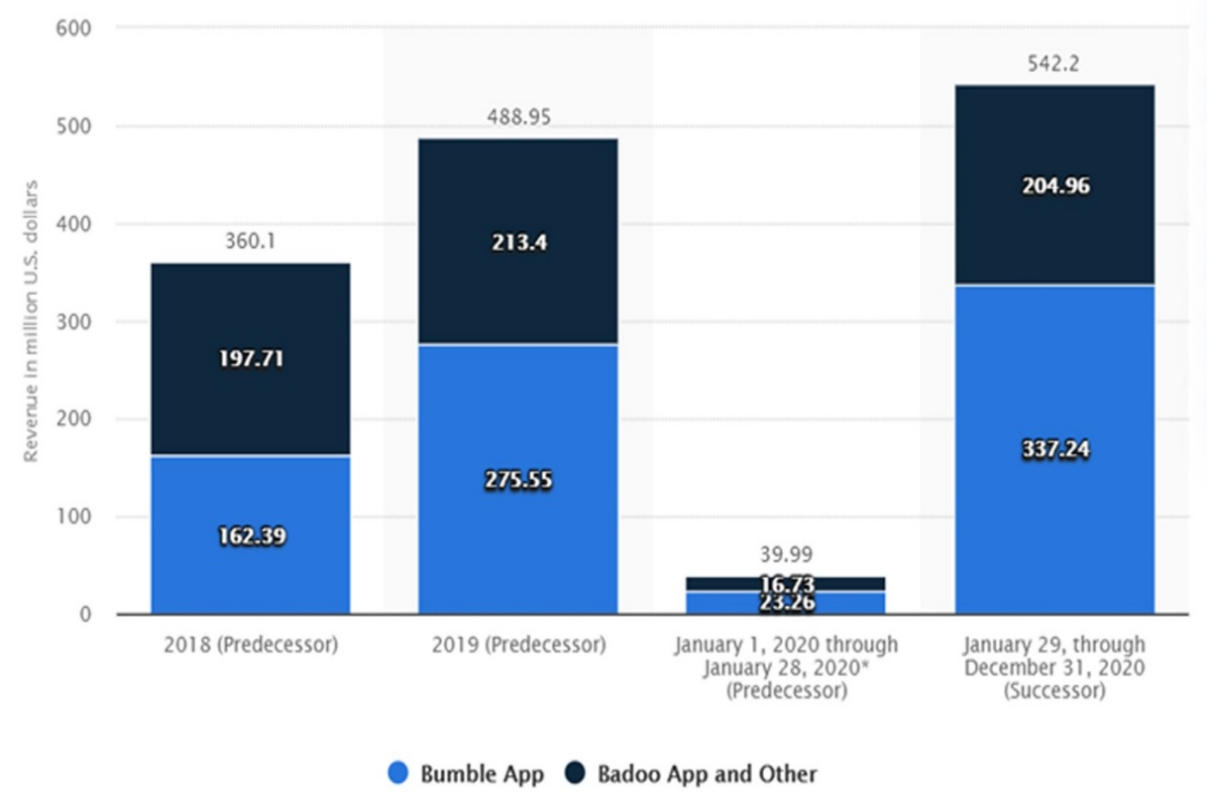

Figure-8: Annual Revenue Generated by Bumble Inc. From 2018 To 2020

Source: (Tankovska, 2021)

The revenues and growth rate of the video conferencing application Zoom, which has become popular with the Covid-19 pandemic, has greatly increased. As seen in Figure 8, the company's revenues reached 883 million dollars as of 2021. Even, security concerns and reports of possibly problematic ties to Chinese authorities notwithstanding, Zoom Video Communications has been a major beneficiary of the changes brought about by the COVID-19 pandemic. As much of the world has been working from home and relying on technology to stay in touch with colleagues and loved ones amid national lockdowns, video conferencing apps saw an unprecedented surge in usage, with Zoom one of the most popular options available. "In FY2021, we significantly scaled our business to provide critical communications and collaboration services to our customers and the global community in response to the pandemic," Eric S. Yuan, Founder and Chief Executive Officer of Zoom said in his company's latest earnings release. "We are humbled by our role as a trusted partner and an engine for the modern work-from-anywhere environment" (Zoom, 2021). As the following chart shows, Zoom saw its revenue skyrocket throughout the fiscal year ended January 31, 2021. Following a 169-percent revenue increase in the first quarter, year-over-year revenue growth accelerated to 355,367 and 369 percent, 
respectively, in the second, third and fourth quarter. For the twelve months ended January 31, Zoom's revenue amounted to $\$ 2.65$ billion, up from just $\$ 623$ million the previous year. The video conferencing company ended the year with a net profit of \$671 million, up from just \$22 million in fiscal 2020. As of March 1, Zoom Video Communications had a market capitalization of $\$ 120$ billion, compared \$31 billion a year earlier (Richter, 2021).

\section{Zoom's Revenue Skyrockets On Pandemic Boost \\ Quarterly revenue of Zoom Video Communications*}

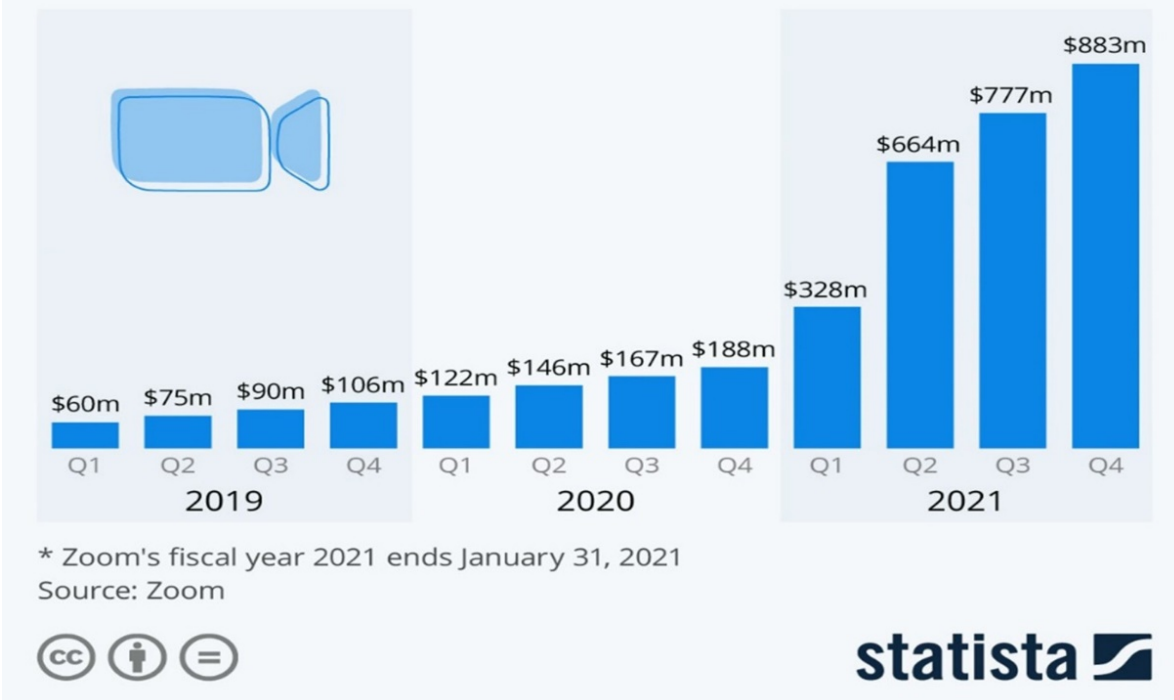

Figure-9: The Rate of Increase of Zoom Application by Years Source: (Richter, 2021)

Apart from live broadcast platforms, online platforms such as Netflix and Spotify have recorded a record rise in the Covid-19 crisis. However, it is also important to highlight that not all cultural and creative sector activities are victims of COVID-19. Online content services benefited from increased demand in subscriptions or on-demand services. Companies like Netflix (BBC News, 2020), Amazon Prime Video, telecom, national VOD services or Spotify enjoyed substantial business growth reflected in increased membership, customers or share price (Fox, 2020). Whilst impacted by the production pause, the streaming giant Netflix gained 26 million paid subscribers. The music-streaming platform 
Spotify witness an increase $(27 \% \mathrm{Y} / \mathrm{Y})$ subscribers in the first two quarters of 2020 (Spotify, 2020).

According to viewers, there are many benefits to live video-streaming events. $79 \%$ feel that it brings more authentic interaction with the audience. Using a live video to promote a product brings a human touch to digital marketing, according to $63 \%$ of people. The benefits of this type of interaction are mutual. $60 \%$ of content creators say it is much easier to get real-time feedback from the audience. Which ultimately helps make the service better. Moreover, in terms of marketing, Facebook Live will be part of $32 \%$ of all video marketing strategies in $2020.67 \%$ of people bought tickets for an event after watching a similar one online. Furthermore, $45 \%$ of live video audiences would pay for live, exclusive, on-demand video from a favourite team, speaker, performer. It's plain to see live streaming is an effective way to attract the public to your concert or sports event (Goglobe, 2021). The live streaming market is growing at a vast rate. Back in 2016 , it was already worth over $\$ 30$ billion. By 2021 , it is expected to be worth over $\$ 70$ billion, meaning it has grown by $133 \%$ since 2016 (Patel, 2021). It is seen that people show the highest demand for live broadcasts in video watching rates. The demand of people for live broadcasts has turned into online consumption in the pandemic crisis.

Back in April 2019, the total number of hours watched on the four major streaming platforms was 1,971 billion. Fast forward to April 2020, and this has increased to 3,934 billion, representing a massive growth of 99\% (Hay, 2020). As seen in the examples, the Covid-19 pandemic is causing an unexpected crisis for the world. This crisis offers a digitalized life with people moving away from each other. Although users cannot be together in the public space, they prefer new virtual meeting environments to socialize. Many activities such as education, conference, concert, theatre, opera, sports competition and award ceremony were held virtually during this process. Zoom, a video conferencing application, has achieved a record rise in the last two years. Online dating apps have grown as well. While concert tickets were sold at higher prices before the Covid-19 virus, they went on sale at lower prices during the pandemic period. This situation, as an advantage, was reflected and caused the audience to expand. A crowd of people too crowded to be in the same environment under normal conditions had the opportunity to watch the same show from different locations at the same time. During the pandemic process, sports competitions were also played without an audience. However, online ticket sales were equal to the team's 1-year ticket sales. These variables created by the online activity economy will also cause many economic areas to be reinterpreted after Covid-19. 


\section{CONCLUSION}

Due to the Covid-19 crisis, people coming together in physical places and being in contact increases the risk of transmission of the disease. For this reason, governments have minimized face-to-face contact in everyday life by quickly setting new rules. This health measure, called social distance, has also caused many activities in everyday life to be interrupted. As a result of this crisis, many social habits have moved to the virtual world. Education, which is mutual contact areas in everyday life, has been moved to digital classrooms and work has been moved to digital offices and has caused a change in social spaces. Although this sudden transformation prevented close contact in everyday life, it could not prevent the socialization instinct of human beings. The rapid change experienced in the education and business sector has also affected art and entertainment activities, which are socialization areas. Many world stars met with the audience by organizing virtual concerts in this process. Although the viewers are in different locations at the same time, they have become able to share their feelings in different places at the same time by participating in a common event in the virtual world. In this process, art events such as theatre and opera have also been moved to digital, offering the audience the opportunity to watch thousands of shows, not just one show, but with weekly or monthly subscriptions. The pandemic has also affected sports competitions, causing most matches to be played without audiences. However, this turned into an advantage, causing online tickets to be sold in higher volumes. Because the virtual environment removes the space constraint, allowing the audience to access the events from anywhere they want. Another advantage created by the Covid-19 crisis is that the events reach more people in the virtual environment. While this situation hinders visibility in physical life, it allows to communicate with more masses in virtual life.

Users who cannot come together in the real environment, form the concept of virtual contact by communicating with their virtual bodies in the digital environment. Now, laughter is replaced by emoji, applause is replaced by likes, and dialogues are replaced by comments. The distance between people during the pandemic process has caused them to get closer in digital life. The inclusion of digital among face-to-face contact also allows a new economy to emerge. Now, people can buy tickets with digital currencies and watch live concerts from wherever they are. They can show their appreciation in the virtual environment by sending gifts to the artist they like instantly in digital currencies. Likewise, while video conferencing applications have achieved a rapid rise, the demand for online dating applications has also increased. Adapting to the virtual world for most sectors during and after the Covid-19 process becomes a necessity 
rather than a choice. In this transformation process, sectors and people who are not adapted to digital life will have to become invisible if they cannot prove their existence in the digital world, which is an extension of real life. This also applies to face-to-face communication. Today, the introduction of camera and screen between face-to-face communication reveals the concept of virtual contact. For this reason, it would not be wrong to say that the concept of virtual contact is the socialization form of the future.

\section{CONFLICT OF INTEREST STATEMENT}

There is no conflict of interest between the authors.

\section{FINANCIAL SUPPORT}

The author(s) received no specific funding or support for this work.

\section{AUTHOR CONTRIBUTIONS}

S.B and A.Y.: Idea, Design, Check, Collection and/or processing of resources, Literature review, Writer,

A.Y.: Crtical evaluation

\section{ETHICS COMMITTEE STATEMENT AND INTELLECTUAL}

\section{PROPERTY COPYRIGHTS}

Ethics committee principles were complied with in the study and necessary permissions were obtained in accordance with the intellectual property and copyright principles.

\section{REFERENCES}

Appel, G., Grewal, L., Hadi, R. et al. (2020). The future of social media in marketing. J. of the Acad. Mark. Sci. 48, 79-95. https://doi.org/10.1007/s11747-019-00695-1

Art Basel \& UBS. (2020). The Impact of COVID-19 on the Gallery Sector: A 2020 midyear survey. Access Date: 26.04.2021. Retrieved from: https://d2u3kfwd92fzu7.cloudfront.net/The_Art_Market_Mid_Year_Survey_2 020-1.pdf

Barrot, J.-N., Grassi, B., \& Sauvagnat, J. (2020). Sectoral Effects of Social Distancing. HEC Paris Research Paper No. FIN-2020-1371, 1-31. http://dx.doi.org/10.2139/ssrn.3569446.

BBC News (2020). Coronavirus: Film piracy streaming trebles in lockdown. $B B C$. Access Date: 18.05.2021. Retrieved from: https://www.bbc.com/news/technology52676254 . 
Beck, R. (2021). The Guardian. Dating apps: is it worth paying a premium to find love? The Guardian. Access Date: 27.05.2021. Retrieved from: https://www.theguardian.com/lifeandstyle/2021/apr/24/dating-apps-premiumfind-love-over-30

Blickley, L. (2020). The 2020 Emmy Awards Were A Virtual Delight. Huff Post. Access Date: 15.05.2021. Retrieved from: https://www.huffpost.com/entry/2020emmys-review_n_5f67ea9bc5b6b9795b12b68a

Bogardus, E. (1925). Measuring social distance. Journal of Applied Sociology, 9, 299308.

Broadway. (n.d.). Broadwayhd. Broadwayhd. Access Date: 05.05.2021. Retrieved from: https://www.broadwayhd.com/

Brown, A. (n.d.). Coronavirus is Changing - Online Dating - Permanently. Forbes. Access Date: 03.06.2021. Retrieved from: https://www.forbes.com/sites/abrambrown/2020/04/05/coronavirus-ischangingonline-dating-permanently/?sh=15a597ab3b22

Bumble. (2021a). Bumble. Bumble. Access Date: 04.06.2021. Retrieved from: https://bumble.com/en/help/what-is-bumble-boost

Bumble. (2021b). A Letter from Bumble's Founder and CEO: Please Date Virtually for Now. Bumble. Access Date: 03.06.2021. Retrieved from: https://bumble.com/en-us/the-buzz/virtualdatingrequest

Chan, A. (2021). Livestreams \& Virtual Concerts to Watch: Week of April 5. Billboard. Access Date: 09.05.2021. Retrieved from: https://www.billboard.com/articles/news/9551085/livestreams-virtual-concertsweek-of-april-5/

Coffeemeetsbagel. (n.d.). We're on a mission to give everyone a chance at love. You in? Coffee Meets Bagel. Access Date: 07.05.2021. Retrieved from: https://coffeemeetsbagel.com/jobs/welcome/

Company, R. S. (n.d.). Royal Shakespeare Company. Royal Shakespeare Company. Access Date: 27.05.2021. Retrieved from: https:/www.rsc.org.uk/

Dahir, I. (2020). BTS's Virtual Concerts Connected People on A Global Scale Not Seen Before the Pandemic. Buzzfeed News. Access Date: 03.05.2021. Retrieved from: https://www.buzzfeednews.com/article/ikrd/bts-map-of-the-soul-one-concertexperience 
Diamond, J.M. (1997). Guns, Germs, and Steel: The Fates of Human Societies. New York: Norton.

Digital Concert Hall. (n.d.). How it Works. Berliner Philharmoniker Digital Concert Hall. Access Date: 27.05.2021. Retrieved from: https://www.digitalconcerthall.com/en/info

Dockterman, E. (2020). The Coronavirus Is Changing How We Date. Experts Think the Shifts May Be Permanent. Time. Access Date: 27.05.2021. Retrieved from: https://time.com/5819187/dating-coronavirus/

Erickson, T., Kellogg, W., Shami, N. S., \& Levine, D. (2020). Telepresence in Virtual Conferences: An Empirical Comparison of Distance Collaboration Technologies. CiteSeerX. Access Date: 05.05.2021. Retrieved from: http://citeseerx.ist.psu.edu/viewdoc/summary?doi=10.1.1.603.814

European Festival Association. (2020). Report on the occasion of the COVID19 survey April - May 2020. Access Date: 13.04.2021. Retrieved from: https://www.efa-aef.eu/media/10870-

report_covid19_survey_festivals_needs_and_commitments.pdf

Fiesse, T. Haas, C. (2020). COVID-19 and true solidarity on the internet. Zenodo. https://doi.org/10.5281/zenodo.3753034

Flora, L. (2020). Instagram Livestreams Surge in Social Distancing Era. Glossy. Access Date: 21.05.2021. Retrieved from: https://www.glossy.co/beauty/instagramlivestreams-surge-in-social-distancing-era

Fox, M. (2020). Spotify surges $17 \%$ after reporting $31 \%$ jump in paid subscribers amid coronavirus lockdowns (SPOT). Business Insider. Access Date: 13.05.2021. Retrieved from: https://markets.businessinsider.com/news/stocks/spotify-stockprice-earnings-report-jump-paid-subscribers-revenuecoronavirus-2020-41029146559.

Frater, P. (2020). BTS' 'Bang Bang Con: The Live' Claims Record Viewership for Online Concert. Variety. Access Date: 06.05.2021. Retrieved from: https://variety.com/2020/digital/asia/bts-big-bang-con-the-live-record-onlineconcert-1234635003/.

Fuchs, C. (2020). Everyday Life and Everyday Communication in Coronavirus $\begin{array}{llll}\text { Capitalism. } & \text { triple } & C & 18,\end{array}$ https://doi.org/10.31269/triplec.v18i1.1167 
Global Yes24. (n.d.). Event. Global Yes24. Access Date: 06.05.2021: Retrieved from: https://global.yes24.com/Event/184257

Go-Globe. (2017). The State of Live Streaming - Statistics and Trends (Infographic). GoGlobe. Access Date: 03.05.2021. Retrieved from: https:/www.goglobe.com/live-streaming-statistics/

Goh, K. T., Cutter, J., Heng, B. H., Ma, S., Koh, B. K., Kwok, C., Toh, C. M., \& Chew, S. K. (2006). Epidemiology and control of SARS in Singapore. Annals of the Academy of Medicine, Singapore, 35(5), 301-316. PMID: 16829997

Google. (2021). Turkey Mobility Changes. Covid-19 Community Mobility Report. Access Date: 01.06.2021. Retrieved from: https://www.gstatic.com/covid19/mobility/2021-0523_TR_Mobility_Report_en.pdf

Guardian, (2020). Dynamo Dresden fans buy 72,000 tickets for match in empty stadium. The Guardian. Access Date: 06.05.2021. Retrieved from: https:/www.theguardian.com/football/2020/dec/23/dynamo-dresden-fans-by72000-tickets-for-match-in-empty-stadium

Haji-Georgi, M. Xu, X, Rosca, O. (2021). Academic conferencing in 2020: A virtual conference model. Human Behavior and Emerging Technologies. 3. 176-184. https://doi.org/10.1002/hbe2.235

Hay, R. (2020). Streaming Platforms Show Massive Growth Since Last Year, Except Mixer. Daily Esports. Access Date: 23.05.2021. Retrieved from: https://daily.upcomer.com/streaming-platforms-show-massive-growth-sincelast-year-except-mixer/

KEA European Affairs. (2020). The impact of the COVID19 pandemic on the Cultural and Creative Sector: Report for the Council of Europe. Access Date: 18.4.2021. Retrieved from: https://keanet.eu/wp-content/uploads/Impact-of-COVID-19pandemic-on-CCS_COE-KEA_26062020.pdf.pdf

Kieferle, J. B. (2000). Virtual Space - New Tasks for Architects. Promise and Reality: State of the Art versus State of Practice in Computing for the Design and Planning Process, 18th eCAADe Conference Proceedings, ISBN 0-9523687-65. 205-208. Weimar, Germany. 
Kraut, R., Patterson, M., Lundmark, V., Kiesler, S., Mukopadhyay, T., \& Scherlis, W. (1998). Internet paradox. A social technology that reduces social involvement and psychological well-being?. The American Psychologist. 53(9), 1017-1031. https://doi.org/10.1037//0003-066x.53.9.1017

Kusuma, P. Sandra Devindriati, (2020) Children Virtual Concert in the Covid-19 Pandemic. Journal of Music Science, Technology and Industry. 3(2), 247-260. https://doi.org/10.31091/jomsti.v3i2.1160

Lefebvre, H. (2014). Critique of Everyday Life, One-Volume Edition, London: Verso.

Lefebvre,H. (1991). The Production of Space, London: Basil Blackweel.

Lokki, T. Savioja, L. Hiipakka, J. Hanninen, R. (1999). Virtual Concerts in Virtual Spaces. The Journal of the Accoustical Society of America, 105, 1-4. https://doi.org/10.1121/1.425348

Maj, E. K. A. (2020). Decoding 2019 Novel Coronavirus: Outbreak: Conspiracies: Impact. India: Blue Rose Publishers.

Mamo, H. (2020). SuperM Promises to Perform Unreleased Songs During Augmented Reality Live Stream Concert SuperM Promises to Perform Unreleased Songs During Augmented Reality Live Stream Concert. Billboard. Access Date: 23.04.2021. Retrieved from: https://www.billboard.com/articles/news/international/9365759/supermaugmented-reality-live-stream-concert

Market Research Future. (2020). Global Live Streaming Market Research Report: By Component (Platforms and Services), By End-User (Media \& Entertainment, Esports, Events, Education, Retail, Government and Others) - Forecast till 2027. Market Research Future. Access Date: 03.06.2021. Retrieved from: https://www.marketresearchfuture.com/reports/live-streaming-market-10134.

Musixen. (n.d). Musixen. Musixen. Access Date: 25.05.2021. Retrieved from: https://www.musixen.com/

Okcupid. (n.d.). Okcupid. Okcupid. Access Date: 03.05.2021. Retrieved from: https://www.okcupid.com/

Patel, N. (n.d.). Why You Should Care About Live Streaming. NeilPatel. Access Date: 07.05.2021. Retrieved from: https://neilpatel.com/blog/live-streamingimportance-2018/ 
Paton, B. (2020). Social change and linguistic change: the language of Covid-19. Oxford English Dictionary Blog. Access Date: 18.05.2021. Retrieved from: https://public.oed.com/blog/the-language-of-covid-19/

Payne, M., York, C., \& Fagan, J. (1974). Changes in Measured Social Distance Over Time. Sociometry, 37(1). 131-136. https://doi.org/10.2307/2786473.

Peuler, M. McCallister K. C. (2018). Virtual and Valued: A Review of the Successes (and a Few Failures) of the Creation, Implementation, and Evaluation of an Inaugural Virtual Conference and Monthly Webinars, Journal of Library \& Information Services in Distance Learning, 13:1-2, 104-114, https://doi.org/10.1080/1533290X.2018.1499240.

Pham, J. (2021). Miley Cyrus Is Performing the Super Bowl Pregame Show-Here's How to Watch it For Free. Yahoo!Life. Access Date: 16.05.2021. Retrieved from: https://www.yahoo.com/lifestyle/miley-cyrus-performing-super-bowl144514351.html?guccounter=1\&guce_referrer=aHR0cHM6Ly93d3cuZ29vZ2 xlLmNvbS8\&guce_referrer_sig=AQAAAB9wccs11SU9M1Wx8xJKffCHs7ib my71TWrWLLXqdw3jM7dfzvSkt_AxR9pdC_i5pr274GA7zDxsiW1COJ_HJ9u4nEmX

Powell, S. (2020). How virtual fans found their seats at NBA season restart. NBA. Access Date: 10.05.2021. Retrieved from: https://www.nba.com/news/virtual-fanshelp-restart-atmosphere

Richter, F. (2021). Zoom's Revenue Skyrockets on Pandemic Boost. Statista. Access Date: 01.06.2021. Retrieved from: https://www.statista.com/chart/21906/zoomrevenue/\#: :text=The\%20video $\% 20$ conferencing\%20company $\% 20$ ended, $\% 24$ $31 \% 20$ billion $\% 20 \mathrm{a} \% 20$ year\%20earlier.

Robins, K. (1996). Into the Image: Culture and Politics in the Field of Vision. London: Routledge.

Social distancing footpath markings in London, United Kingdom. By Acabashi (https://commons.wikimedia.org/wiki/User:Acabashi) under CC-BY-SA 4.0.

Spotify (2020). Spotify Technology S.A. Announces Financial Results for Second Quarter 2020. Spotify. Access Date: 10.05.2021. Retrieved from: https://investors.spotify.com/financials/press-release-details/2020/SpotifyTechnology-S.A.-Announces-Financial-Results-for-Second-Quarter2020/default.aspx

Stalder, F. (2014). Digitale Solidarität. Berlin: Rosa-Luxemburg-Stiftung. 
Tankovska, H. (2021). Annual revenue generated by Bumble Inc. from 2018 to 2020, by app. Statista. Access Date: 30.05.2021. Retrieved from: https://www.statista.com/statistics/1231967/annual-bumble-revenue-by-app/.

The Social Distancing Festival. (n.d.). About of The Social Distancing Festival About. Social Distancing Festival. Access Date: 19.05.2021. Retrieved from: https://www.socialdistancingfestival.com/about

Tomova, L., Wang, K., Thompson, T., Matthews, G., Takahashi, A., Tye, K., \& Saxe, R. (2020). The need to connect: Acute social isolation causes neural craving responses similar to hunger. bioRxiv, 2020.03.25.006643. https://doi.org/10.1101/2020.03.25.006643

Towner, E. Ladensack, D. Callaghan, B. (2021). Welcome to My Zoom Party - Virtual Social Interaction, Loneliness, and Well-Being Among Emerging Adults Amid the COVID-19 Pandemic. PsyArXiv. https://doi.org/10.31234/osf.io/2ghtd

Vandenberg, F. Berghman, M. Schaap, J. (2021). The 'lonelyraver': music livestreams during COVID-19 as a hotline to collective consciousness?. European Societies, 23(1), 141-152, https://doi.org/10.1080/14616696.2020.1818271

WHO. (n.d.). Coronavirus disease (COVID-19) pandemic. World Health Organization. Access Date: 06.05.2021. Retrieved from: https://www.who.int/emergencies/diseases/novel-coronavirus-2019

Wilder-Smith, A, Freedman, D. O. (2020). Isolation, quarantine, social distancing and community containment: pivotal role for old-style public health measures in the novel coronavirus (2019-nCoV) outbreak. Journal of Travel Medicine. (27),2. https://doi.org/10.1093/jtm/taaa020

Willman, C. (2020). BTS' Weekend Virtual Concerts Sell 993,000 Tickets. Variety. Access Date: 29.05.2021. Retrieved from: https:/variety.com/2020/music/news/bts-virtual-concerts-map-soul-pay-perview-tickets-1234801571/

Y1ldırım, A. (2020a). Digital Pandemic in Digital Age: Covid-19 Agenda in Turkey. Intermedia International E-journal (in Turkish), 7 (13), 381-401. Retrieved from: https://dergipark.org.tr/en/pub/intermedia/issue/58521/822991.

Yıldırım, A. (2020b). YouTuber Phenomenon in Turkey and YouTube Analysis by View Types. Yeni Medya (in Turkish), 2020 (9), 52-70. Retrieved from: https://dergipark.org.tr/en/pub/yenimedya/issue/58796/830336 
Zoom. (2021). Zoom Video Communications Reports Fourth Quarter and Fiscal Year 2021 Financial Results. Zoom. Access Date: 19.05.2021. Retrieved from: https://investors.zoom.us/news-releases/news-release-details/zoom-videocommunications-reports-fourth-quarter-and-fiscal-0 